\title{
Detoxification of hydrogen sulfide and methanethiol in the cecal mucosa
}

\author{
Michael D. Levitt, Julie Furne, John Springfield, Fabrizis Suarez, and Eugene DeMaster \\ Research Service, Minneapolis Veterans Affairs Medical Center, Minneapolis, Minnesota 55417, USA \\ Address correspondence to: Michael D. Levitt, Minneapolis Veterans Affairs Medical Center (151), 1 Veterans Drive, Minneapolis, \\ Minnesota 55417, USA. Phone: (612) 725-2033; Fax: (612) 725-2093.
}

Received for publication June 28, 1999, and accepted in revised form August 30, 1999.

\begin{abstract}
Colonic bacteria liberate large quantities of the highly toxic gases hydrogen sulfide $\left(\mathrm{H}_{2} \mathrm{~S}\right)$ and methanethiol $\left(\mathrm{CH}_{3} \mathrm{SH}\right)$. The colonic mucosa presumably has an efficient means of detoxifying these compounds, which is thought to occur through methylation of $\mathrm{H}_{2} \mathrm{~S}$ to $\mathrm{CH}_{3} \mathrm{SH}$ and $\mathrm{CH}_{3} \mathrm{SH}$ to dimethylsulfide $\left(\mathrm{CH}_{3} \mathrm{SCH}_{3}\right)$. We investigated this detoxification pathway by incubating rat cecal mucosal homogenates with gas containing $\mathrm{H}_{2} \mathrm{~S}, \mathrm{CH}_{3} \mathrm{SH}$, or $\mathrm{CH}_{3} \mathrm{SCH}_{3}$. Neither $\mathrm{CH}_{3} \mathrm{SH}$ nor $\mathrm{CH}_{3} \mathrm{SCH}_{3}$ was produced during $\mathrm{H}_{2} \mathrm{~S}$ catabolism, whereas catabolism of $\mathrm{CH}_{3} \mathrm{SH}$ liberated $\mathrm{H}_{2} \mathrm{~S}$ but not $\mathrm{CH}_{3} \mathrm{SCH}_{3}$. Thus, $\mathrm{H}_{2} \mathrm{~S}$ and $\mathrm{CH}_{3} \mathrm{SH}$ are not detoxified by methylation to $\mathrm{CH}_{3} \mathrm{SCH}_{3}$. Rather, $\mathrm{CH}_{3} \mathrm{SH}$ is demethylated to $\mathrm{H}_{2} \mathrm{~S}$, and $\mathrm{H}_{2} \mathrm{~S}$ is converted to nonvolatile metabolites. HPLC analysis of the homogenate showed the metabolite to be primarily thiosulfate. Analysis of cecal venous blood obtained after intracecal instillation of $\mathrm{H}_{2}{ }^{35} \mathrm{~S}$ revealed that virtually all absorbed $\mathrm{H}_{2} \mathrm{~S}$ had been oxidized to thiosulfate. The oxidation rate of $\mathrm{H}_{2} \mathrm{~S}$ by colonic mucosa was 10,000 times greater than the reported methylation rate. Conversion to thiosulfate appears to be the mechanism whereby the cecal mucosa protects itself from the injurious effects of $\mathrm{H}_{2} \mathrm{~S}$ and $\mathrm{CH}_{3} \mathrm{SH}$, and defects in this detoxification possibly could play a role in colonic diseases such as ulcerative colitis.
\end{abstract}

J. Clin. Invest. 104:1107-1114 (1999).

\section{Introduction}

The colonic bacteria produce large quantities of hydrogen sulfide $\left(\mathrm{H}_{2} \mathrm{~S}\right)$ and methanethiol $\left(\mathrm{CH}_{3} \mathrm{SH}\right)$, highly toxic compounds with $\mathrm{LD}_{50}$ 's for rodents that are on the same order of magnitude as cyanide. Given the very high exposure of the colonic mucosa to $\mathrm{H}_{2} \mathrm{~S}$ and $\mathrm{CH}_{3} \mathrm{SH}$, local tissue damage would be expected if the mucosa did not possess an efficient detoxification mechanism. The possibility that sulfide might be injurious to colonic mucosa was first proposed by Roediger and Nance (1), who postulated that excess sulfide production could play an etiological role in ulcerative colitis.

A variety of high-molecular-weight thiols are detoxified in a methylation reaction catalyzed by thiol $S$-methyltransferase (2-4). Recent literature assumes that a similar mechanism is used in the detoxification of the lowmolecular-weight thiols $\mathrm{H}_{2} \mathrm{~S}$ and $\mathrm{CH}_{3} \mathrm{SH}$ (5-8). Such methylation would result in the conversion of $\mathrm{H}_{2} \mathrm{~S}$ to $\mathrm{CH}_{3} \mathrm{SH}$, and then $\mathrm{CH}_{3} \mathrm{SH}$ to dimethylsulfide $\left(\mathrm{CH}_{3} \mathrm{SCH}_{3}\right)$, a relatively nontoxic compound. However, the reported rate of methylation of $\mathrm{H}_{2} \mathrm{~S}$ by rat colonic mucosa is only about $10^{-13} \mathrm{~mol} / \mathrm{min}$ per milligram of protein (8). This activity appears to be many orders of magnitude less than that required to metabolize $\mathrm{H}_{2} \mathrm{~S}$ released in the colon, which we found to occur at a rate of about $10^{-7} \mathrm{~mol} / \mathrm{min}$ in the rat cecum (9).

In the process of incubating $\mathrm{H}_{2} \mathrm{~S}$ and $\mathrm{CH}_{3} \mathrm{SH}$ with rat cecal mucosa, we observed that both gases disappeared far more rapidly than could be accounted for by reported methylation rates. The present report describes in vitro and in vivo experiments demonstrating that the colonic mucosa possesses a very efficient, but largely unrecognized, system to metabolize $\mathrm{H}_{2} \mathrm{~S}$ and $\mathrm{CH}_{3} \mathrm{SH}$. This system proceeds, not by methylation, but rather by demethylation of $\mathrm{CH}_{3} \mathrm{SH}$ to $\mathrm{H}_{2} \mathrm{~S}$ and oxidation of $\mathrm{H}_{2} \mathrm{~S}$ primarily to thiosulfate.

\section{Methods}

Tissues. Cecal and hepatic tissues were obtained from male Sprague-Dawley rats (300-400 g) while the animals were under pentobarbital anesthesia. The cecum was first cleansed of luminal debris by rinsing with isotonic saline, and the mucosa was then scraped off using the edge of a glass microscope slide. Tissue samples were maintained on ice until homogenized in an ice-cold buffer solution in a ratio of 1 part tissue to 15 parts buffer (wt/vol). Homogenization was performed with a Duall grinder (Kontes, Vineland, New Jersey, USA) with a Teflon pestle, using 8-10 strokes. Except when noted, studies were carried out using RPMI buffer, which has a $\mathrm{pH}$ of 7.4 when equilibrated with $5 \% \mathrm{CO}_{2}$. This buffer contains a variety of electrolytes, including $0.4 \mathrm{mM}$ sulfate. In addition, some studies were carried out in $0.1 \mathrm{M}$ PBS ( $\mathrm{pH} 7.0$ ) or a buffer system containing $1.15 \% \mathrm{KCl}, 5 \mathrm{mM}$ Tris- $\mathrm{HCl}(\mathrm{pH}$ 7.8 ), and $0.475 \mathrm{mM}$ of the methyl donor $S$-adenosylmethionine, a milieu used in previously published studies (7) designed to assess thiol S-methyltransferase activity. Incubation studies. A $32-\mu \mathrm{L}$ volume of homogenate or buffer was added to 20 - $\mathrm{mL}$ polypropylene syringes. (Preliminary studies showed that both $\mathrm{H}_{2} \mathrm{~S}$ and $\mathrm{CH}_{3} \mathrm{SH}$ reacted rapidly with glass and most plastic surfaces, but had only minimal reactivity with polypropylene.) Ten milliliters of gas containing $\mathrm{H}_{2} \mathrm{~S}, \mathrm{CH}_{3} \mathrm{SH}$, and $\mathrm{CH}_{3} \mathrm{SCH}_{3}$, either as a mixture of the 3 gases or each gas singly, was then 
added to the syringes, which were sealed with stopcocks. In some experiments, $\mathrm{H}_{2}{ }^{35} \mathrm{~S}$ or $\mathrm{CH}_{3}{ }^{35} \mathrm{SH}$ was also added to the gas space. In most studies, the bulk gas was nitrogen containing $5 \% \mathrm{CO}_{2}$; however, some $\mathrm{O}_{2}$ was consistently present in these incubations, because of the atmosphere in the dead spaces of the syringe and stopcock, and in the buffer that was not deoxygenated. The $\mathrm{PO}_{2}$ of the gas space averaged $7 \mathrm{mmHg}$ in these experiments. In selected studies, the influence of a higher $\mathrm{PO}_{2}$ on the reaction rate was studied using air as the gas space, and the influence of a very low $\mathrm{PO}_{2}$ was determined using rigorously deoxygenated reagents and a glove box. The role of thiol $S$ methyltransferase in $\mathrm{H}_{2} \mathrm{~S}$ metabolism was investigated by comparing the rate of $\mathrm{H}_{2} \mathrm{~S}$ disappearance in the presence or absence of the thiol $S$-methyltransferase inhibitor $S$ adenosyl-L-homocysteine ( $2 \mathrm{mM})$.

The syringes were incubated at $37^{\circ} \mathrm{C}$. In studies in which the metabolism of the sulfur gases was determined by assessment of disappearance from the gas space, 1-mL aliquots of gas were removed for analysis at 30 and 60 minutes of incubation. In experiments where metabolism of the sulfur gases was quantitated by incorporation of the radioactive gas into the homogenate, the incubation was carried out for 5 minutes. All gas in the syringe was then rapidly expelled, and the syringe was immediately placed in boiling water for 1 minute to stop the reaction.

In vivo studies. The in vivo metabolism of $\mathrm{H}_{2}{ }^{35} \mathrm{~S}$ and $\mathrm{CH}_{3}{ }^{35} \mathrm{SH}$ was investigated as follows. Under pentobarbital anesthesia, the cecum was cannulated via the terminal ileum using a catheter (1.52- $\mathrm{mm}$ internal diameter). The catheter was secured with a ligature around the ileum. All fecal material in the cecum was flushed into the more distal colon by an infusion of isotonic saline and gentle stripping. The cecal-colonic junction was then ligated. Two milliliters of nitrogen containing $\mathrm{H}_{2}{ }^{35} \mathrm{~S}$ or $\mathrm{CH}_{3}{ }^{35} \mathrm{SH}$ was infused into the isolated cecum. The concentrations of sulfur-containing gases in this infusate ranged from 24,000 to $68,000 \mathrm{ppm}$, and contained about $1 \mu \mathrm{Ci}$ of radioactivity. For the 1-minute period after the cecal instillation of gas, blood was constantly withdrawn from a vein draining the cecum; then a blood sample was obtained from the heart. The gas space was removed from the cecum for analysis, the rat was sacrificed, and then a sample of cecal mucosa was obtained.

Synthesis of $\mathrm{H}_{2}{ }^{35} \mathrm{~S}$ and $\mathrm{CH}_{3}{ }^{35} \mathrm{SH}$. Because neither of these gases is commercially available, and their shelf-life is only a few days, it was necessary to synthesize these compounds on a daily basis as follows. Freshly passed rat feces were homogenized in a blender (Eberbach Corp., Ann Arbor, Michigan, USA) using 1 part feces to 4 parts PBS (pH 7.0). Fifty microcuries of $\left[{ }^{35} \mathrm{~S}\right]$ sodium sulfate, $\left[{ }^{35} \mathrm{~S}\right]$ cysteine, or $\left[{ }^{35} \mathrm{~S}\right]$ methionine was added to $10 \mathrm{~mL}$ of homogenate, and the mixture was incubated in a sealed $50-\mathrm{mL}$ polypropylene syringe along with $40 \mathrm{~mL}$ of nitrogen. The gas space was removed at 24 hours, and $\mathrm{H}_{2}{ }^{35} \mathrm{~S}$ and $\mathrm{CH}_{3}{ }^{35} \mathrm{SH}$ were isolated by their differential adsorption to MTO-Tenax-TA (80/100 mesh; Supelco, Bellefonte, Pennsylvania, USA). The gas space was passed through a glass column containing Tenax (43 $\mathrm{mm} \times 5$ $\mathrm{mm} ; 150 \mathrm{mg}$ ) maintained on dry ice. Both gases were completely adsorbed at this temperature. $\mathrm{H}_{2} \mathrm{~S}, \mathrm{CH}_{3} \mathrm{SH}$, and $\mathrm{CH}_{3} \mathrm{SCH}_{3}$ were differentially desorbed by heating the column from $25^{\circ} \mathrm{C}$ to $100^{\circ} \mathrm{C}$ as nitrogen was passed through the column. The purity of the sulfur gas preparations was confirmed by gas chromatography.

Gas chromatography. Samples $(0.30 \mathrm{~mL})$ were analyzed for $\mathrm{H}_{2} \mathrm{~S}, \mathrm{CH}_{3} \mathrm{SH}$, and $\mathrm{CH}_{3} \mathrm{SCH}_{3}$ using a gas chromatograph (model 5890; Hewlett-Packard, Palo Alto, California, USA) equipped with a Teflon column $(8 \mathrm{ft} \times 0.125$ in, packed with Chromosil 330 [Supelco], maintained at $80^{\circ} \mathrm{C}$ with a flow rate of $20 \mathrm{~mL} / \mathrm{m}$ ) and a sulfur chemiluminescence detector (model 355; Sievers Instruments, Boulder, Colorado, USA), which is specific for sulfurcontaining gases. The identity of the gases was initially verified using gas chromatography/mass spectroscopy, and subsequently by measuring retention times. The gases were quantitated by comparison of peak areas with the areas of authentic standards.

Radioactivity and protein measurements. The radioactivity in the gas space was determined by adding $1 \mathrm{~mL}$ of gas to $0.3 \mathrm{~mL}$ of $0.2 \mathrm{~N}$ hyamine contained in a $5-\mathrm{mL}$ polypropylene syringe. (Preliminary studies showed that both $\mathrm{H}_{2} \mathrm{~S}$ and $\mathrm{CH}_{3} \mathrm{SH}$ were avidly taken up by hyamine.) The hyamine $(0.1 \mathrm{~mL})$ was then added to $10 \mathrm{~mL}$ of Ultima Gold (Packard Instrument Co., Meriden, Connecticut, USA) and radioactivity determined by scintillation counting (Packard Instrument Co., Downers Grove, Illinois, USA). The radioactivity of the homogenates was determined after treatment with $1 \mathrm{~N} \mathrm{HCl}$ to drive off dissolved $\mathrm{H}_{2} \mathrm{~S}$ and $\mathrm{CH}_{3} \mathrm{SH}\left(0.3 \mathrm{~mL}\right.$ of $1 \mathrm{~N} \mathrm{HCl}_{\text {was }}$ added to $32 \mu \mathrm{L}$ of homogenate). The acidified homogenate $(0.1$ $\mathrm{mL}$ ) was added to $10 \mathrm{~mL}$ of Ultima Gold, and radioactivity was determined by scintillation counting. The protein content of the tissue homogenates was determined by the Coomassie protein assay (Pierce Chemical Co., Rockford, Illinois, USA), using BSA as a standard.

HPLC. The nonvolatile metabolites produced during incubation of tissue with $\mathrm{H}_{2}{ }^{35} \mathrm{~S}$ and $\mathrm{CH}_{3}{ }^{35} \mathrm{SH}$ were identified by HPLC (model C-R3A Chromatopac; Shimadzu Corp., Kyoto, Japan) run at $2 \mathrm{~mL} / \mathrm{min}$ and 2,000 psi, using an anion-ion exchange column (IonPac AS16; Dionex Corp., Salt Lake City, Utah, USA) and a conductivity monitor (Amersham Pharmacia Biotech, Piscataway, New Jersey, USA) for mass measurements. For radioactivity measurements, the column eluate was collected in $2.0-\mathrm{mL}$ fractions in individual scintillation vials, and the radioactivity of these fractions was determined as described above. The retention times of the unknowns were compared with retention times of authentic standards.

Calculation of metabolism. In studies where metabolic rate was determined from the fall in concentration of the sulfur compound in the gas space, metabolism was assumed to equal the disappearance rate of the compound when incubated with the tissue homogenate minus the disappearance rate observed with the buffer control. In studies where metabolic rate was determined by incorporation of radioactivity into the homogenate, metabolism was calculated from the radioactivity of the tissue-containing homogenate minus that of the buffer control.

\section{Results}

Disappearance of $\mathrm{H}_{2} \mathrm{~S}, \mathrm{CH}_{3} \mathrm{SH}$, and $\mathrm{CH}_{3} \mathrm{SCH}_{3}$ during incubation with cecal mucosa and liver. Figure 1 shows typical gaschromatographic patterns of aliquots of the gas space 

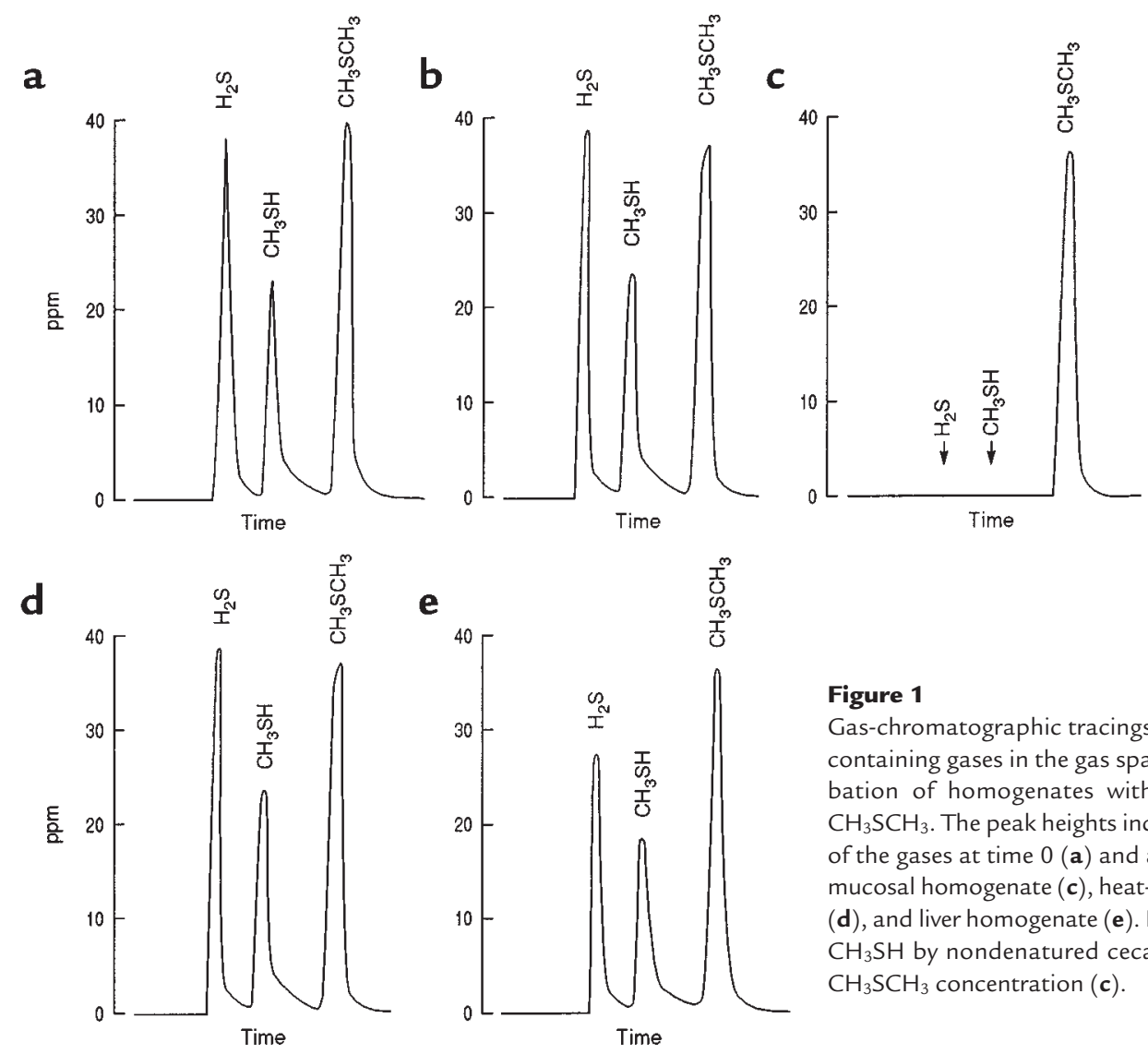

\begin{abstract}
Figure 1
Gas-chromatographic tracings showing the concentration of sulfurcontaining gases in the gas space before and after a 60-minute incubation of homogenates with gas containing $\mathrm{H}_{2} \mathrm{~S}, \mathrm{CH}_{3} \mathrm{SH}$, and $\mathrm{CH}_{3} \mathrm{SCH}_{3}$. The peak heights indicate the approximate concentrations of the gases at time 0 (a) and after incubation with buffer $(\mathbf{b})$, cecal mucosal homogenate (c), heat-denatured cecal mucosal homogenate (d), and liver homogenate (e). Note the complete removal of $\mathrm{H}_{2} \mathrm{~S}$ and $\mathrm{CH}_{3} \mathrm{SH}$ by nondenatured cecal mucosa with minimal alteration in $\mathrm{CH}_{3} \mathrm{SCH}_{3}$ concentration (c).
\end{abstract}

obtained 60 minutes after gas containing a mixture of $\mathrm{H}_{2} \mathrm{~S}, \mathrm{CH}_{3} \mathrm{SH}$, and $\mathrm{CH}_{3} \mathrm{SCH}_{3}$ ( 40 ppm of each gas) was incubated with buffer or a homogenate of rat cecal mucosa or liver. A minimal decrease in the concentrations of the test gases was observed during incubation with buffer (Figure 1b). During incubation with cecal tissue, the change in $\mathrm{CH}_{3} \mathrm{SCH}_{3}$ concentration was similar to that observed with buffer, whereas both $\mathrm{H}_{2} \mathrm{~S}$ and $\mathrm{CH}_{3} \mathrm{SH}$ were entirely eliminated from the gas space during the 60-minute incubation (Figure 1c). Heating the tissue homogenate at $100^{\circ} \mathrm{C}$ for 5 minutes before the incubation abolished the ability of the tissue to metabolize $\mathrm{H}_{2} \mathrm{~S}$ or $\mathrm{CH}_{3} \mathrm{SH}$ (Figure 1d). As shown in Figure 1e, hepatic tissue metabolized $\mathrm{H}_{2} \mathrm{~S}$ and $\mathrm{CH}_{3} \mathrm{SH}$, but at a much slower rate than was observed with cecal mucosa, and there was no detectable metabolism of $\mathrm{CH}_{3} \mathrm{SCH}_{3}$.

Figure 2 shows the gas-chromatographic tracings of the gas space obtained during incubation of cecal mucosa or buffer with $\mathrm{H}_{2} \mathrm{~S}, \mathrm{CH}_{3} \mathrm{SH}$, or $\mathrm{CH}_{3} \mathrm{SCH}_{3}$. The minimal disappearance of $\mathrm{CH}_{3} \mathrm{SCH}_{3}$ during incubation with cecal mucosa was similar to that with incubation with buffer (Figure 2, top). Thus, the failure to observe an increase in concentration of $\mathrm{CH}_{3} \mathrm{SCH}_{3}$ when incubated as a mixture with $\mathrm{H}_{2} \mathrm{~S}$ and $\mathrm{CH}_{3} \mathrm{SH}$ (Figure 1) was not due to a fortuitous balance between production and catabolism, but rather to an inability of the tissue to produce (or catabolize) $\mathrm{CH}_{3} \mathrm{SCH}_{3}$.

During the incubation of cecal homogenate with $\mathrm{H}_{2} \mathrm{~S}$ neither $\mathrm{CH}_{3} \mathrm{SH}$ nor $\mathrm{CH}_{3} \mathrm{SCH}_{3}$ appeared (Figure 2, middle). The metabolism of $\mathrm{CH}_{3} \mathrm{SH}$ by mucosa was not associated with the appearance of $\mathrm{CH}_{3} \mathrm{SCH}_{3}$, but consistent- ly resulted in the transient appearance of a small $\mathrm{H}_{2} \mathrm{~S}$ peak (Figure 2, bottom). Similar results were obtained when phosphate buffer or a $1.15 \% \mathrm{KCl}$ buffer system containing the methyl donor $S$-adenosylmethionine was used. Figure 3 shows the lack of production of $\mathrm{CH}_{3} \mathrm{SH}$ or $\mathrm{CH}_{3} \mathrm{SCH}_{3}$ during the metabolism of $\mathrm{H}_{2} \mathrm{~S}$ by a cecal homogenate supplemented with $S$-adenosylmethionine.

To exclude the possibility that methylation of $\mathrm{H}_{2} \mathrm{~S}$ to $\mathrm{CH}_{3} \mathrm{SH}$ was being obscured by extremely rapid metabolism of $\mathrm{CH}_{3} \mathrm{SH}$ in the experiments shown in Figure 2, cecal homogenate was incubated with gas containing a low concentration of $\mathrm{H}_{2}{ }^{35} \mathrm{~S}$ and a relatively high concentration of $\mathrm{CH}_{3} \mathrm{SH}$ to "trap" $\mathrm{CH}_{3}{ }^{35} \mathrm{SH}$ released during metabolism of $\mathrm{H}_{2}{ }^{35}$ S. Disappearance of the $\mathrm{H}_{2} \mathrm{~S}$ was not associated with the appearance of radioactivity in the $\mathrm{CH}_{3} \mathrm{SH}$ peak. In contrast, when a low concentration of $\mathrm{CH}_{3}{ }^{35} \mathrm{SH}$ and a relatively high concentration of $\mathrm{H}_{2} \mathrm{~S}$ were incubated with cecal mucosa, more than $50 \%$ of the radioactivity of the metabolized $\mathrm{CH}_{3}{ }^{35} \mathrm{SH}$ was found in the $\mathrm{H}_{2} \mathrm{~S}$ peak.

Influence of $\mathrm{PO}_{2}$ and an inhibitor of thiol S-methyltransferase on reaction rates. Compared with the reaction rates observed in our standard assay $\left(\mathrm{PO}_{2} \sim 8 \mathrm{mmHg}\right)$, at ambient $\mathrm{PO}_{2}$ the metabolism of $\mathrm{H}_{2} \mathrm{~S}$ and $\mathrm{CH}_{3} \mathrm{SH}$ by cecal mucosa was increased by $40 \%$ and $103 \%$, respectively, and at very low $\mathrm{PO}_{2}$ the metabolic rates were reduced by $36 \%$ and $78 \%$, respectively. The presence of the thiol $S$-methyltransferase inhibitor adenosyl-L-homocysteine did not inhibit $\mathrm{H}_{2} \mathrm{~S}$ metabolism by cecal mucosa (the rate with inhibitor/rate without inhibitor ratio averaged $1.03 \pm 11$ in 3 studies).

Quantitation of metabolic rate. The rates of metabolism of $\mathrm{H}_{2} \mathrm{~S}$ and $\mathrm{CH}_{3} \mathrm{SH}$, as determined by disappearance rate 
from the gas space during the first 30 minutes of the study, averaged $1.8 \pm 0.13$ and $1.7 \pm 0.13 \mathrm{nmol} / \mathrm{min}$ per milligram of protein, respectively. Interpretation of these metabolic rates was complicated, because the concentration of substrate, which initially was well below saturating, decreased markedly during the 30-minute incubation. To more accu-
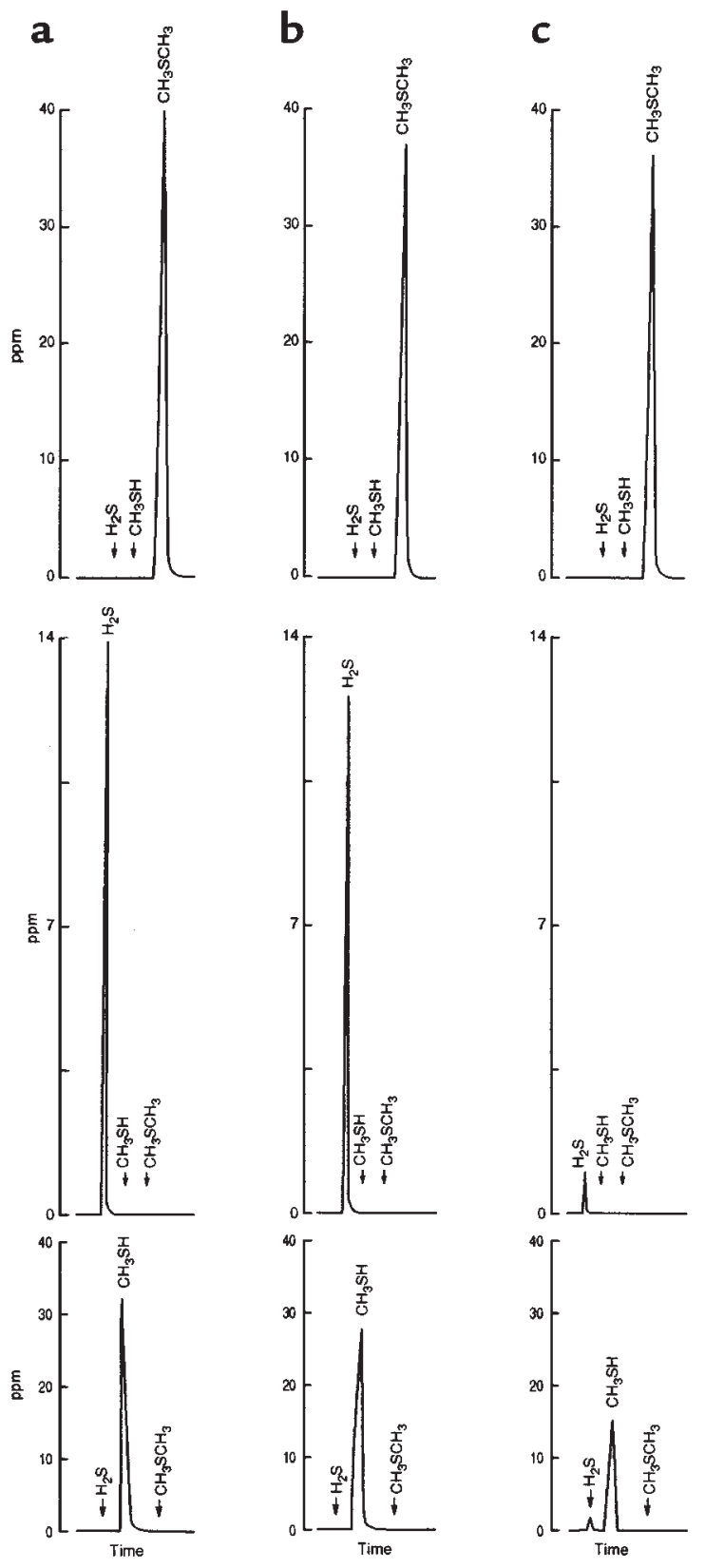

\section{Figure 2}

Gas-chromatographic tracings showing the concentration of sulfur-containing gases in the gas space before and after incubation of cecal homogenate with gas containing $\mathrm{CH}_{3} \mathrm{SCH}_{3}$ (top), $\mathrm{H}_{2} \mathrm{~S}$ (middle), and $\mathrm{CH}_{3} \mathrm{SH}$ (bottom). Tracings denoted a were obtained at time 0 , whereas those denoted $\mathbf{b}$ and $\mathbf{c}$ are the results obtained after a 10-minute incubation with buffer and cecal mucosal homogenates, respectively. Note the inability of the mucosa to metabolize $\mathrm{CH}_{3} \mathrm{SCH}_{3}$ (top), the absence of $\mathrm{CH}_{3} \mathrm{SH}$ or $\mathrm{CH}_{3} \mathrm{SCH}_{3}$ production during the metabolism of $\mathrm{H}_{2} \mathrm{~S}$ by cecal mucosa (middle), and the appearance of $\mathrm{H}_{2} \mathrm{~S}$, but not $\mathrm{CH}_{3} \mathrm{SCH}_{3}$, during the metabolism of $\mathrm{CH}_{3} \mathrm{SH}$ by cecal mucosa (bottom). rately assess the rate of $\mathrm{H}_{2} \mathrm{~S}$ metabolism, measurements were made of the rate at which ${ }^{35} \mathrm{~S}$ was incorporated into cecal or liver homogenates as nonvolatile metabolites during a 5-minute incubation with $\mathrm{H}_{2}{ }^{35} \mathrm{~S}$. Figure 4 shows a plot of the rate at which cecal mucosa incorporated $\mathrm{H}_{2}{ }^{35} \mathrm{~S}$ into nonvolatile metabolites in the homogenate versus $\mathrm{H}_{2} \mathrm{~S}$ concentration in the gas phase. Saturation was observed at a gas space $\mathrm{H}_{2} \mathrm{~S}$ concentration of about $150 \mathrm{ppm}$. The $\mathrm{V}_{\max }$ of this reaction was calculated to be $21 \mathrm{nmol} / \mathrm{min}$ per milligram of protein, and the $K_{\mathrm{m}}$ was about $25 \mathrm{ppm}$. At an $\mathrm{H}_{2} \mathrm{~S}$ concentration of $150 \mathrm{ppm}$, the rate of $\mathrm{H}_{2} \mathrm{~S}$ metabolism by hepatic homogenates averaged $2.5 \mathrm{nmol} / \mathrm{min}$ per milligram of protein.

Metabolic products of $\mathrm{H}_{2}{ }^{35} \mathrm{~S}$ metabolism by the cecal mucosa and liver. In the in vitro studies, $\mathrm{H}_{2}{ }^{35} \mathrm{~S}$ or $\mathrm{CH}_{3}{ }^{35} \mathrm{SH}$ was incubated with cecal mucosa, and the reaction was allowed to continue until neither sulfur gas nor $\mathrm{CH}_{3} \mathrm{SCH}_{3}$ was detectable by gas chromatography. At this time, scintillation counting of the gas space showed no radioactivity, indicating that no volatile metabolite had been formed. The radioactivity was quantitatively recovered in the homogenate. Figure 5 shows the HPLC elution patterns of authentic sulfate, thiosulfate, and thiocyanate, as well as the radioactivity elution patterns of cecal or hepatic homogenates after incubation with $\mathrm{H}_{2}{ }^{35} \mathrm{~S}$. Virtually all the radioactivity (average: 94\%) in the cecal homogenates eluted coincident with thiosulfate (Figure $5 \mathrm{~b}$ ). Similar results were observed when $\mathrm{CH}_{3} \mathrm{SH}$ was metabolized by cecal mucosa (data not shown). When the incubation mixture contained $1 \mathrm{mM}$ cyanide, the fraction of the radioactivity eluting as thiosulfate decreased, and radioactivity now appeared coincident with the thiocyanate peak (Figure $5 \mathrm{c}$ ). Homogenates of hepatic tissue converted approximately equal amounts of the radioactivity to sulfate (mean: $42 \%$ ) and thiosulfate (mean: 47\%).

In the in vivo studies, 1 minute after $\mathrm{H}_{2}{ }^{35} \mathrm{~S}$ infusion into the cecum, an average of only $6 \%$ of the radioactivity remained in the cecum. Figure 6 a shows the HPLC elution pattern of serum radioactivity of cecal blood obtained over a 1-minute period after infusion of $\mathrm{H}_{2}{ }^{35} \mathrm{~S}$ into the cecum. Virtually all the radioactivity eluted with thiosulfate. When the serum was acidified and equilibrated with air, no radioactivity was liberated into the gas space, indicating that no detectable $\mathrm{H}_{2}{ }^{35} \mathrm{~S}$ or any other volatile sulfur-containing compound was present in the blood. HPLC analysis of serum obtained from blood collected by cardiac puncture at 1 minute showed most of the radioactivity to be present as sulfate (Figure 6b).

\section{Discussion}

The acute toxicity of $\mathrm{H}_{2} \mathrm{~S}$ and $\mathrm{CH}_{3} \mathrm{SH}$ appears to result, like that of cyanide, from the inhibition of cytochrome oxidase. In vitro measurements have shown that $\mathrm{H}_{2} \mathrm{~S}$ actually is a slightly more potent inhibitor of cytochrome oxidase than is cyanide (10).

Whereas the danger of externally administered $\mathrm{H}_{2} \mathrm{~S}$ and $\mathrm{CH}_{3} \mathrm{SH}$ is well recognized, there has been less appreciation of the potential problems that could result from endogenous exposure to these compounds. The maximum environmental $\mathrm{H}_{2} \mathrm{~S}$ exposure allowed by government regulations is an atmospheric concentration of 10 ppm for 10 minutes, and evacuation of the facility is 
required if the concentration reaches $50 \mathrm{ppm}$, a level that is injurious to both the eyes and the lungs (11). We have observed $\mathrm{H}_{2} \mathrm{~S}$ concentrations in excess of $1,000 \mathrm{ppm}$ in gas samples taken from the rat cecum (9). If inhaled, an $\mathrm{H}_{2} \mathrm{~S}$ concentration of 1,000 ppm induces paralysis, coma, and death within minutes (11).

Most available information on the mechanisms involved in fecal $\mathrm{H}_{2} \mathrm{~S}$ and $\mathrm{CH}_{3} \mathrm{SH}$ production has been derived from studies of fecal homogenates or cultures of fecal bacteria. Fecal $\mathrm{H}_{2} \mathrm{~S}$ production may result from the action of sulfate-reducing bacteria, a genera of organisms that use sulfate as an electron acceptor during the dissimulation of various compounds, including $\mathrm{H}_{2}$. In the process, sulfate is reduced to sulfide. However, sulfur-containing compounds of endogenous origin, such as mucin, taurocholate, and cysteine, are converted to $\mathrm{H}_{2} \mathrm{~S}$ far more efficiently by human fecal homogenates than sulfate (12). Thus, these endogenous sources of sulfur could be a major substrate for the bacterial production of $\mathrm{H}_{2} \mathrm{~S}$ in the colon, as opposed to sulfate, which is derived from the diet. Supplementation of human fecal homogenates with sulfate also increases $\mathrm{CH}_{3} \mathrm{SH}$ production; however, methionine is a much better substrate for the bacterial production of this gas (12).

Concentrations of $\mathrm{H}_{2} \mathrm{~S}$ and $\mathrm{CH}_{3} \mathrm{SH}$ in human flatus collected by rectal tube ranged from 0.01 to $30 \mathrm{ppm}$ (13). Fecal specimens passed by healthy controls released $\mathrm{H}_{2} \mathrm{~S}$ and $\mathrm{CH}_{3} \mathrm{SH}$ at mean rates of about 7 and $5 \mu \mathrm{L} / \mathrm{h}$ per gram of dry weight, respectively (12), and rat fecal specimens released these gases at approximately the same rate. To more accurately assess the intracolonic production of $\mathrm{H}_{2} \mathrm{~S}$ and $\mathrm{CH}_{3} \mathrm{SH}$, we carried out studies on rats fitted with chronically implanted cecal cannulae that provided access to the unperturbed cecum (9). When 3 $\mathrm{mL}$ of nitrogen was instilled into the cecum, $\mathrm{H}_{2} \mathrm{~S}$ and $\mathrm{CH}_{3} \mathrm{SH}$ accumulated in the gas phase at rates of roughly 2.6 and $0.096 \mu \mathrm{L} / \mathrm{min}$, respectively. When expressed as gas release per gram of fecal material, this rate of $\mathrm{H}_{2} \mathrm{~S}$ release was about 30 times greater than that observed with rat feces passed per rectum. It should be noted that the observed accumulation rate of the $\mathrm{H}_{2} \mathrm{~S}$ and $\mathrm{CH}_{3} \mathrm{SH}$ in cecal gas represents the net of liberation minus absorption/destruction by the colonic mucosa. To assess this absorption/destruction rate, nitrogen containing $\mathrm{H}_{2} \mathrm{~S}, \mathrm{CH}_{3} \mathrm{SH}, \mathrm{H}_{2}$, and $\mathrm{CH}_{4}$ was rapidly infused into the rat cecum, and gas was collected at the rectum. Over 95\% of the $\mathrm{H}_{2} \mathrm{~S}$ and $\mathrm{CH}_{3} \mathrm{SH}$ disappeared during the 3- to 4minute transit time through the colon, a disappearance rate that was more than 20 times more rapid than that observed for $\mathrm{H}_{2}$ or $\mathrm{CH}_{4}$. Studies in which $\mathrm{H}_{2} \mathrm{~S}$ labeled with ${ }^{35} \mathrm{~S}$ was infused into the cecum showed that about $95 \%$ of the $\mathrm{H}_{2} \mathrm{~S}$ was turned over each minute (9). Thus, conclusions drawn from studies of flatus composition, fecal gas production, or even cecal gas composition all yield dramatic underestimates of the true exposure of the colon to the sulfur-containing gases.

Although indirect, measurements of methane excretion possibly offer a means of estimating sulfide production in the human colon. The vast majority of $\mathrm{H}_{2}$ released by fecal bacteria is consumed by other bacteria (14). The major $\mathrm{H}_{2}$ consuming organisms are methanogens and sulfatereducing bacteria, which use $\mathrm{H}_{2}$ to reduce $\mathrm{CO}_{2}$ to methane

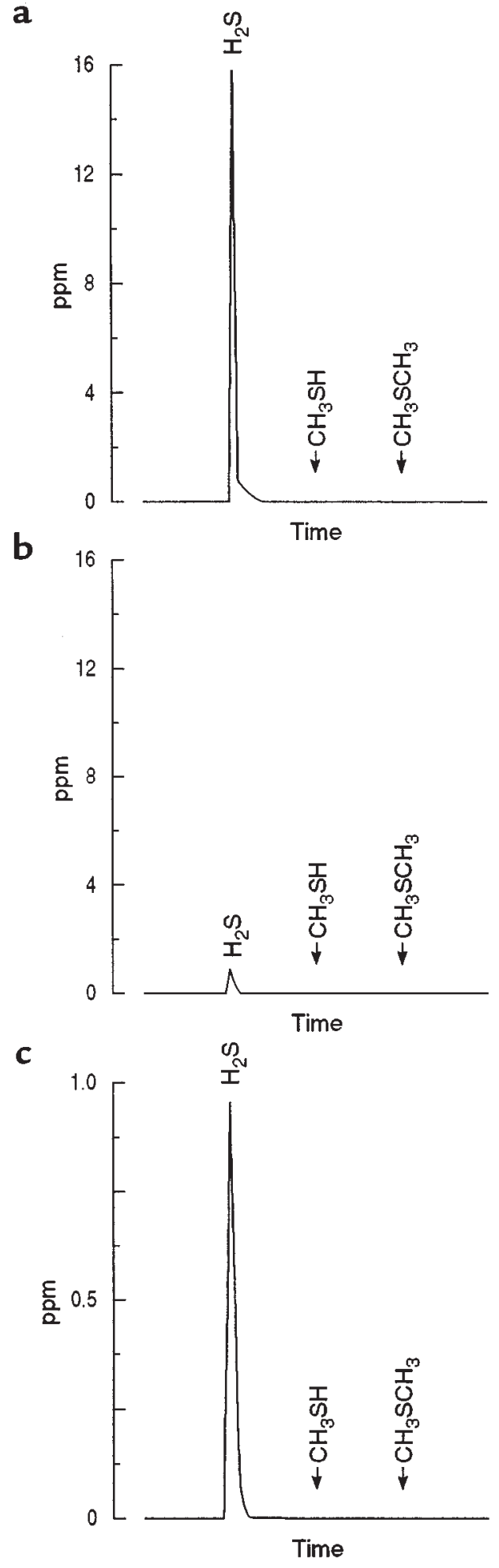

Figure 3

Gas-chromatographic tracings show the concentrations of sulfur-containing gases in the gas space before and after a 60-minute incubation of cecal homogenate with a gas space initially containing $\mathrm{H}_{2} \mathrm{~S}$. In contrast to the studies shown in Figures 1 and 2, in this study the buffer was supplemented with the methyl donor $S$-adenosylmethionine. Similarly attenuated measurements of the sulfur gas concentrations present at 0 and 60 minutes are shown in a and $\mathbf{b}$, respectively. Most of the $\mathrm{H}_{2} \mathrm{~S}$ had been metabolized by 60 minutes, with no evidence of $\mathrm{CH}_{3} \mathrm{SH}$ or $\mathrm{CH}_{3} \mathrm{SCH}_{3}$ production (b). (c) The same recording shown in $\mathbf{b}$, with the attenuation reduced by 16 -fold. Even with $16-$ fold "magnification," no $\mathrm{CH}_{3} \mathrm{SH}$ nor $\mathrm{CH}_{3} \mathrm{SCH}_{3}$ evolution could be identified. 
and sulfate to sulfide, respectively $(15,16)$. In these reactions, $4 \mathrm{~mol}$ of $\mathrm{H}_{2}$ are used in the process of reducing 1 mol of $\mathrm{CO}_{2}$ or sulfate. Because methanogens and sulfatereducing bacteria compete for $\mathrm{H}_{2}$, human fecal samples

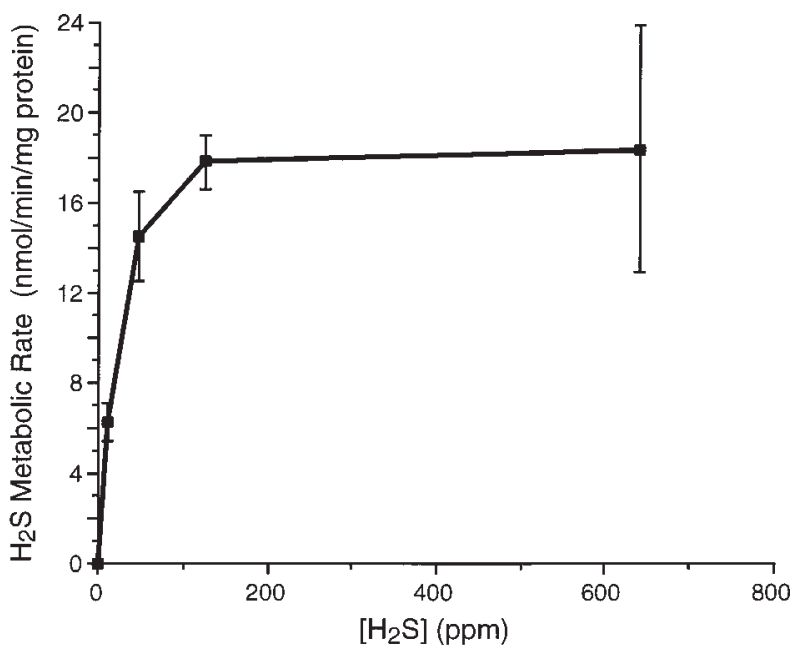

\section{Figure 4}

Plot of disappearance rate of $\mathrm{H}_{2} \mathrm{~S}$ from gas space versus $\mathrm{H}_{2} \mathrm{~S}$ concentration in the gas space during incubation with cecal homogenate. Maximal rate of metabolism was about $21 \mathrm{nmol} / \mathrm{min}$ per milligram of tissue.

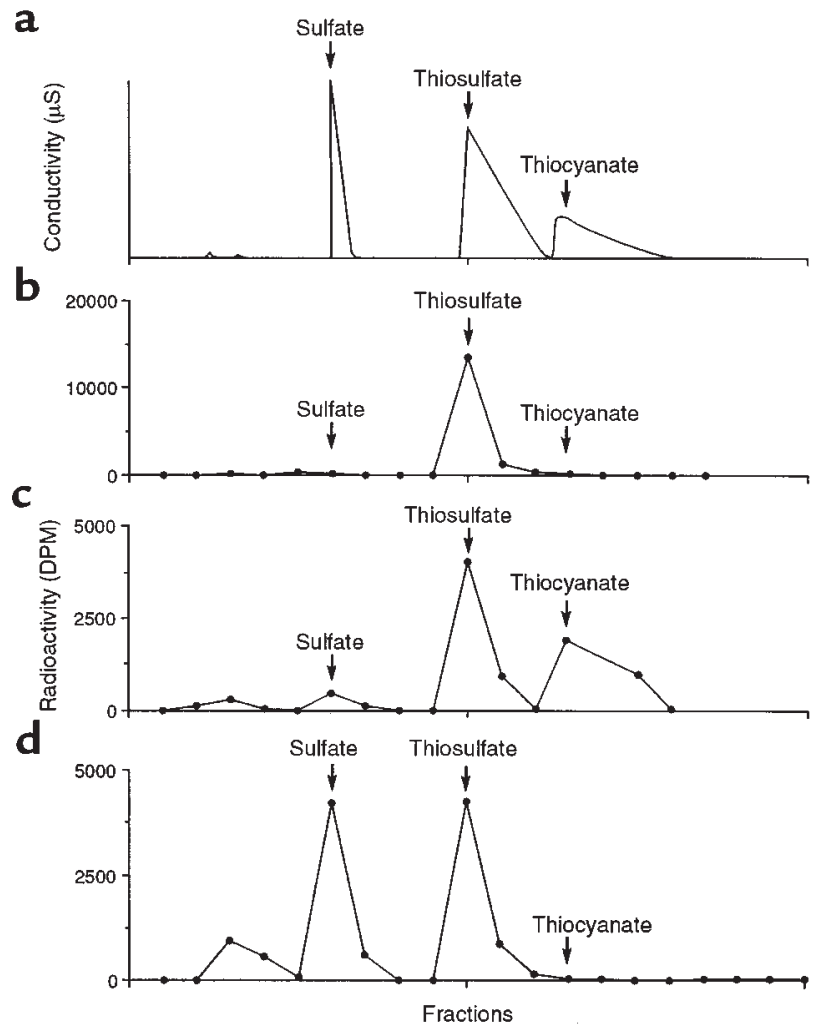

Figure 5

HPLC patterns of ${ }^{35} \mathrm{~S}$ in homogenates of cecal mucosa or liver after incubation with $\mathrm{H}_{2}{ }^{35} \mathrm{~S}$. (a) The elution pattern of authentic standards of sulfate, thiosulfate, and thiocyanate. (b-d) The radioactivity in sulfate, thiosulfate, and thiocyanate peaks after incubation of with $\mathrm{H} 2^{35} \mathrm{~S}$ cecal mucosa without cyanide (b) or with cyanide (c), or after incubation of liver tissue without cyanide $(\mathbf{d})$. generally contain high concentrations of just 1 of these 2 types of bacteria (16). Because methanogens in the human colon produce methane solely through the oxidation of $\mathrm{H}_{2}$ released by other organisms, the excretion of methane by subjects with a predominantly methanogenic flora should provide an indirect estimate of the rate of sulfide production in subjects with predominantly sulfide-reducing flora. High excretors of methane eliminate up to 50 mmol of this gas per day (17), suggesting that nonmethanogenic subjects may dispose of similar quantities of $\mathrm{H}_{2}$ through the production of up to $50 \mathrm{mmol}$ of $\mathrm{H}_{2} \mathrm{~S}$ per day. This value is a minimal estimate, because sulfate can be reduced by a number of reactions other than the oxidation of $\mathrm{H}_{2}$. The potential toxicity of $50 \mathrm{mmol}$ of $\mathrm{H}_{2} \mathrm{~S}$ is appreciable. For example, given an $\mathrm{LD}_{50} \mathrm{Of}_{2} \mathrm{~S}$ for mice of about $0.02 \mathrm{mmol}$ (administered over 1 hour), $50 \mathrm{mmol}$ would be sufficient to kill roughly 1,250 mice.

The enormous amounts of $\mathrm{H}_{2} \mathrm{~S}$ and $\mathrm{CH}_{3} \mathrm{SH}$ produced in the colon almost certainly would produce local tissue damage (and possibly systemic toxicity) if colonic tissue did not have an efficient means of detoxifying these compounds. Most of the literature on this topic suggests that this detoxification occurs by methylation, a reaction that would convert $\mathrm{H}_{2} \mathrm{~S}$ to $\mathrm{CH}_{3} \mathrm{SH}$ and $\mathrm{CH}_{3} \mathrm{SH}$ to $\mathrm{CH}_{3} \mathrm{SCH}_{3}$ (5-8). Our initial goal was to measure the rate of methylation by incubating cecal mucosal homogenates with $\mathrm{H}_{2} \mathrm{~S}, \mathrm{CH}_{3} \mathrm{SH}$, and $\mathrm{CH}_{3} \mathrm{SCH}_{3}$, as a mixture (Figure 1) or singly (Figure 2). These experiments showed that cecal tissue rapidly metabolized $\mathrm{H}_{2} \mathrm{~S}$ and $\mathrm{CH}_{3} \mathrm{SH}$, but had no discernible ability to metabolize $\mathrm{CH}_{3} \mathrm{SCH}_{3}$. If $\mathrm{H}_{2} \mathrm{~S}$ and $\mathrm{CH}_{3} \mathrm{SH}$ were being converted to $\mathrm{CH}_{3} \mathrm{SCH}_{3}$ (as would necessarily be the case with methylation), the metabolism of $\mathrm{H}_{2} \mathrm{~S}$ and $\mathrm{CH}_{3} \mathrm{SH}$ should result in the appearance of $\mathrm{CH}_{3} \mathrm{SCH}_{3}$. However, no such $\mathrm{CH}_{3} \mathrm{SCH}_{3}$ production was observed during the rapid elimination of $\mathrm{H}_{2} \mathrm{~S}$ and $\mathrm{CH}_{3} \mathrm{SH}$ by cecal mucosa. Similar results were observed with several different buffer preparations, including a buffer milieu used in measurements of thiol $S$-methyltransferase activity that contained a marked excess of the methyl donor S-adenosylmethionine. Additional evidence against the existence of appreciable methylation of $\mathrm{H}_{2} \mathrm{~S}$ and $\mathrm{CH}_{3} \mathrm{SH}$ was the finding that metabolism of these gases was not inhibited by the addition of $S$-adenosyl-L-homocysteine, an inhibitor of $S$-methyltransferases, to the homogenates (18).

Experiments using $\mathrm{H}_{2}{ }^{35} \mathrm{~S}$ showed that neither $\mathrm{CH}_{3}{ }^{35} \mathrm{SH}$ nor $\mathrm{CH}_{3}{ }^{35} \mathrm{SCH}_{3}$ was detectable during $\mathrm{H}_{2}{ }^{35} \mathrm{~S}$ metabolism. However, $\mathrm{CH}_{3}{ }^{35} \mathrm{SH}$ metabolism resulted in the production of labeled $\mathrm{H}_{2} \mathrm{~S}$, but not $\mathrm{CH}_{3} \mathrm{SCH}_{3}$. When the metabolism of $\mathrm{H}_{2}{ }^{35} \mathrm{~S}$ and $\mathrm{CH}_{3}{ }^{35} \mathrm{SH}$ was allowed to proceed to completion, no radioactive metabolite was found in the gas space, and the ${ }^{35} \mathrm{~S}$ of both labeled compounds was quantitatively recovered in the liquid homogenate. Thus, in contrast to the previous assumption that $\mathrm{H}_{2} \mathrm{~S}$ and $\mathrm{CH}_{3} \mathrm{SH}$ are detoxified by methylation to the volatile metabolite $\mathrm{CH}_{3} \mathrm{SCH}_{3}$, we found that $\mathrm{CH}_{3} \mathrm{SH}$ was demethylated to $\mathrm{H}_{2} \mathrm{~S}$, and $\mathrm{H}_{2} \mathrm{~S}$ was disposed of by a reaction that converted this gas to a nonvolatile metabolite.

Studies using HPLC were carried out to identify the end products of $\mathrm{H}_{2}{ }^{35} \mathrm{~S}$ and $\mathrm{CH}_{3}{ }^{35} \mathrm{SH}$ metabolism by cecal mucosal homogenates. These studies showed that the vast bulk of the ${ }^{35} \mathrm{~S}$ in the homogenate eluted coincident 
with thiosulfate, and most of the remainder eluted with sulfate. We took advantage of the naturally occurring rhodanese activity of the cecal mucosa to obtain chemical evidence that the labeled peak eluting with thiosulfate was truly thiosulfate. Rhodanese catalyzes the reaction of thiosulfate and cyanide to form thiocyanate. When mucosa was incubated with $\mathrm{H}_{2}{ }^{35} \mathrm{~S}$ and cyanide, an appreciable fraction of the material, tentatively identified as $\left[{ }^{35} \mathrm{~S}\right]$ thiosulfate, was converted to a compound that eluted coincident with thiocyanate.

To determine if our in vitro observation of $\mathrm{H}_{2} \mathrm{~S}$ and $\mathrm{CH}_{3} \mathrm{SH}$ oxidation to thiosulfate accurately reflected in vivo metabolism, studies were carried out in the intact rat. HPLC studies of cecal venous blood obtained immediately after $\mathrm{H}_{2}{ }^{35} \mathrm{~S}$ instillation into the cecum showed that virtually all plasma radioactivity was present as $\left[{ }^{35} \mathrm{~S}\right]$ thiosulfate. In contrast, analysis of systemic blood showed that radioactivity was present as both thiosulfate and sulfate, indicating that the liver or some other organ converted thiosulfate to sulfate. Surprisingly, when rats were sacrificed several minutes after the cecal instillation of $\mathrm{H}_{2}{ }^{35} \mathrm{~S}$, virtually no $\left[{ }^{35} \mathrm{~S}\right]$ thiosulfate remained in the cecal mucosa. Thiosulfate has been widely used as an indicator of extracellular fluid volume because of its very slow penetrance of tissue membranes (19). The rapid release of thiosulfate from the cecal mucosa suggests that these cells may possess a thiosulfate secretory mechanism.

An assay using an excess of ${ }^{35} \mathrm{~S}$-labeled $\mathrm{H}_{2} \mathrm{~S}$ was developed to quantitate the rate of tissue metabolism of $\mathrm{H}_{2} \mathrm{~S}$ to nonvolatile metabolites. The rate of metabolism of $\mathrm{H}_{2} \mathrm{~S}$ by cecal tissue, which averaged $21 \mathrm{nmol} / \mathrm{min}$ per milligram of protein, was about 8 times that of hepatic tissue. This $8: 1$ activity ratio contrasts with reported measurements of thiol $S$-methyltransferase activity, which showed roughly equal activity in colonic mucosa and liver (8).

The reported rate of methylation of $\mathrm{H}_{2} \mathrm{~S}$ by colonic mucosa (8), $127 \mathrm{fmol} / \mathrm{min}$ per milligram of protein, is only about $1 / 10,000$ the rate of $\mathrm{H}_{2} \mathrm{~S}$ oxidation observed in the present study. In contrast to the methylation rate, the oxidation of $\mathrm{H}_{2} \mathrm{~S}$ observed in the present study is of the order of magnitude required to metabolize all $\mathrm{H}_{2} \mathrm{~S}$ produced in the rat cecum, and hence could protect the cecal mucosa from the injurious potential of this compound.

It has been proposed that sulfide toxicity may be important in the pathogenesis of ulcerative colitis. The initial evidence in this regard was the demonstration that experimental exposure of colonic tissue to sulfide caused inhibition of butyrate use, a defect similar to that observed in colonic mucosal biopsies obtained from subjects with ulcerative colitis $(20,21)$. Subsequent studies showed that the colons of patients with ulcerative colitis may be exposed to unusually high quantities of sulfide, as there are higher-than-normal numbers and activity of sulfate-reducing bacteria in feces of subjects with ulcerative colitis (22). In addition, feces of subjects with ulcerative colitis released $\mathrm{H}_{2} \mathrm{~S}$ about 4 times faster than did feces of healthy controls (12).

Incubation of cecal mucosa with $\mathrm{H}_{2} \mathrm{~S}$ and low concentrations of cyanide resulted in the conversion of thiosulfate to thiocyanate. This observation could explain the well-documented observation that cigarette smoking is beneficial in ulcerative colitis. Smoking increases blood cyanide levels, and the colon has been shown to extract cyanide from blood (23). This cyanide could enhance the removal of thiosulfate from the colonic mucosa, and thus facilitate the metabolism of sulfide to thiosulfate.

The demonstration that cecal mucosa possesses a highly developed enzyme system to detoxify $\mathrm{H}_{2} \mathrm{~S}$ and $\mathrm{CH}_{3} \mathrm{SH}$ could have important clinical implications. To date, studies of the potential pathogenic role of $\mathrm{H}_{2} \mathrm{~S}$ and $\mathrm{CH}_{3} \mathrm{SH}$ in ulcerative colitis have primarily focused on the finding of increased fecal production of these compounds. It also is possible that defective metabolism of $\mathrm{H}_{2} \mathrm{~S}$ or $\mathrm{CH}_{3} \mathrm{SH}$, either genetic or acquired, could allow mucosal accumulation of these compounds, with resultant tissue injury. In addition to the acute injury that results from inhibition of cytochromes, these thiols can react with sulfhydryl-containing compounds to form persulfides (protein-SH $+\mathrm{HS}^{-} \rightarrow$ protein-S-SH $+\mathrm{H}^{+}+2 \mathrm{e}^{-}$ or protein-S-S-protein + HS $-\rightarrow$ protein-S-SH + protein$\mathrm{SH})$. These reactions not only alter protein function, but might change antigenicity. Thus, tissue damage caused by the thiols could result in the chronic, immune-mediated processes that have been demonstrated in ulcerative colitis. Unlike many hypotheses concerning the pathogenesis of ulcerative colitis, the concept of defective mucosal detoxification of $\mathrm{H}_{2} \mathrm{~S}$ and/or $\mathrm{CH}_{3} \mathrm{SH}$ is readily testable - by analysis of colonic mucosal biopsies obtained through colonoscopy.

\section{Acknowledgments}

Supported in part by the Department of Veterans Affairs and National Institute of Diabetes and Digestive

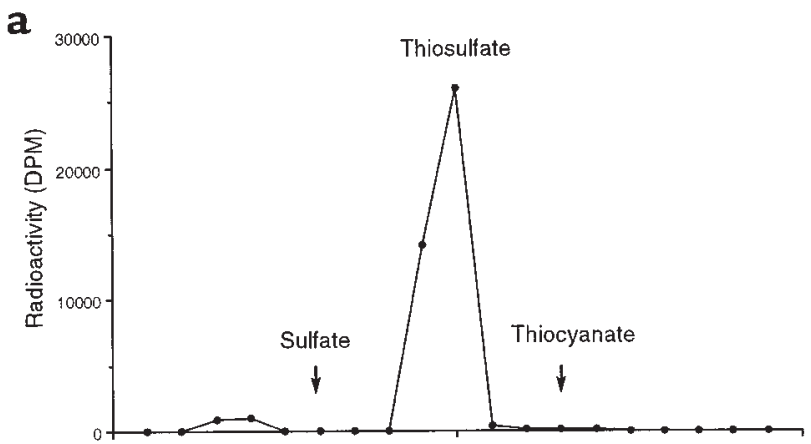

b

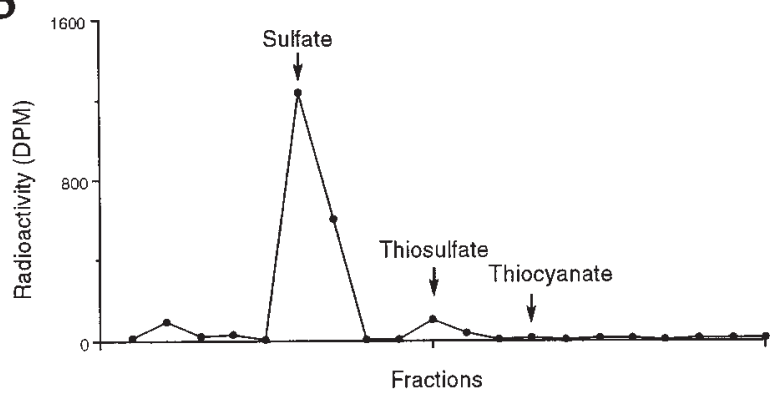

Figure 6

HPLC patterns of plasma radioactivity after infusion of $\mathrm{H}_{2}{ }^{35} \mathrm{~S}$ into the rat cecum. (a) The radioactivity of cecal blood collected during the first minute after $\mathrm{H}_{2}{ }^{35} \mathrm{~S}$ infusion. (b) The radioactivity of systemic blood obtained at 1 minute. 


\section{and Kidney Diseases grant R01 DK 13309-25.}

1. Roediger, W.E.W., and Nance, S. 1990. Selective reduction of fatty acid oxidation in colonocytes: correlation with ulcerative colitis. Lipids. 25:646-652.

2. Bremer, J., and Greenberg, D.M. 1961. Enzymatic methylation of foreign sulfhydryl compounds. Biochim. Biophys. Acta. 46:217-224.

3. Keith, R.A., Otterness, D.M., Kerremans, A.L., and Weinshilboum, R.M. 1985. S-methylation of D- and L-penicillamine by human erythrocyte membrane thiol methyltransferase. Drug Metab. Dispos. 83:669-676.

4. Woodson, L.C., Dunnette, J.H., and Weinshilboum, R.M. 1982. Pharmacogenetics of human thiopurine methyltransferase: kidney-erythrocyte correlation and immunotitration studies. J. Pharmacol. Exp. Ther. 222:174-181.

5. Roediger, W.E.W., Moore, J., and Babidge, W. 1997. Colonic sulfide in pathogenesis and treatment of ulcerative colitis. Dig. Dis. Sci. 42:1571-1579.

6. Roediger, W.E.W., Babidge, W., and Millard, S. 1996. Methionine derivatives diminish sulphide damage to colonocytes: implications for ulcerative colitis. Gut. 39:77-81.

7. Pitcher, M.C.L., Beatty, E.R., Harris, R.M., Waring, R.H., and Cummings, J.H. 1998. Sulfur metabolism in ulcerative colitis investigation of detoxification enzymes in peripheral blood. Dig. Dis. Sci. 43:2080-2085.

8. Weisiger, R.A., Pinkus, L.M., and Jakoby, W.B. 1980. Thiol S-methyltransferase: suggested role in detoxication of intestinal hydrogen sulfide. Biochem. Pharmacol. 29:2885-2887.

9. Suarez, F.L., Furne, J., Springfield, J., and Levitt, M.D. 1998. Production and elimination of sulfur-containing gases in the rat colon. Am. J. Physiol. 274:G727-G733.

10. Nicholls, P. 1975. The effect of sulphide on cytochrome aa $a_{3}$ Isoteric and allosteric shifts of the reduced alpha-peak. Biochim. Biophys. Acta. 396:24-35.

11. Ellenhorn, M.J. 1997. Respiratory toxicology. In Ellenhorn's medical toxicology: diagnosis and treatment of human poisoning. 2nd edition. M.J. Ellenhorn, S. Schonwald, G. Ordog, and J. Wasserberger, editors. Williams \& Wilkins. Baltimore, MD. 1489-1493.

12. Levine, J., Ellis, C.J., Furne, J.K., Springfield, J., and Levitt, M.D. 1998.
Fecal hydrogen sulfide production in ulcerative colitis. Am. J. Gastroenterol. 93:83-87.

13. Suarez, F.L., Springfield, J., and Levitt, M.D. 1998. Identification of gases responsible for the odour of human flatus and evaluation of a device purported to reduce this odour. Gut. 43:100-104.

14 Strocchi, A., and Levitt, M.D. 1992. Factors affecting hydrogen production and consumption by human fecal flora. The critical roles of hydrogen tension and methanogenesis. J. Clin. Invest. 89:1304-1311.

15. Gibson, G.R., Macfarlane, G.T., and Cummings, J.H. 1988. Occurrence of sulphate-reducing bacteria in human faeces and the relationship of dissimilatory sulphate reduction to methanogenesis in the large gut. $J$. Appl. Bacteriol. 65:103-111.

16. Christl, S.U., Gibson, G.R., and Cummings, J.H. 1992. Role of dietary sulphate in the regulation of methanogenesis in the human large intestine. Gut. 33:1234-1238.

17. Christl, S.U., Murgatroyd, P.R., Gibson, G.R., and Cummings, J.H. 1992. Production, metabolism, and excretion of hydrogen in the large intestine. Gastroenterology. 102:1269-1277.

18. Borchardt, R.T., and Cheng, C.F. 1978. Purification and characterization of rat liver microsomal thiol methyltransferase. Biochim. Biophys. Acta. 522:340-353.

19. Cardozo, R.H., and Edelman, I.S. 1952. The volume of distribution of thiosulfate as a measure of the extracellular fluid. J. Clin. Invest. 31:280-290.

20. Roediger, W.E.W., et al. 1993. Sulphide impairment of substrate oxidation in rat colonocytes: a biochemical basis for ulcerative colitis? Clin. Sci. 85:623-627.

21. Chapman, M.A.S., et al. 1994. Butyrate oxidation is impaired in the colonic mucosa of sufferers of quiescent ulcerative colitis. Gut. 35:73-76.

22. Gibson, G.R., Cummings, J.H., and Macfarlane, G.T. 1991. Growth and activities of sulphate-reducing bacteria in gut contents of healthy subjects and patients with ulcerative colitis. FEMS Microbiol. Excol. 86:103-112.

23. Clemedson, C.J., Sorbo, B., and Ullberg, S. 1960. Autoradiographic observations on injected $\mathrm{S}^{35}$-thiocyanate and $\mathrm{C}^{14}$ cyanide in mice. Acta Physiol. Scand. 48:382-389. 